\title{
Physiological and Biochemical Characterization of Jiló Seeds (Solanum gilo) in Different Harvest Times
}

\author{
Marcus Vinicius Prado Alves*, Edila Vilela De Resende Von Pinho, Heloisa Oliveira Dos Santos, \\ Gustavo Costa Prado Alves, Rucyan Walace Pereira
}

Agriculture Department, Federal University of Lavras, Lavras, Brazil

Email: *ordapsevla@yahoo.com.br

How to cite this paper: Alves, M.V.P., Von Pinho, E.V.R., Santos, H.O., Alves, G.C.P. and Pereira, R.W. (2017) Physiological and Biochemical Characterization of Jiló Seeds (Solanum gilo) in Different Harvest Times. American Journal of Plant Sciences, 8, 2569-2595.

https://doi.org/10.4236/ajps.2017.810174

Received: June 30, 2017

Accepted: September 26, 2017

Published: September 29, 2017

Copyright $\odot 2017$ by authors and Scientific Research Publishing Inc. This work is licensed under the Creative Commons Attribution International License (CC BY 4.0).

http://creativecommons.org/licenses/by/4.0/ (c) (i) Open Access

\begin{abstract}
The evaluation of seed quality during the development process is important for the definition of the moment of harvest. In this context, the objective in this study was to evaluate the quality of Jilo seeds during development through physiological, biochemical and electrophoretic tests of enzymes. Six genetic materials, JIL white, JIL 001, JIL 005, JIL 006, H1 and H2 were used. Fruits were harvested at 35, 40, 45 days after anthesis (DAA). A total of $50 \%$ of all fruits harvested at $45 \mathrm{DAA}$ remained at rest for seven days which were labeled as 45 DAAr. The seeds at each maturation stage were extracted from the fruits and evaluated by water content, weight of one thousand seeds, electric conductivity, germination, germination speed index, seedling emergence, and seedling emergence rate index. The chemical composition of the seeds was also evaluated, as well as the expression of the enzymes esterase, isocitrate lyase, malate dehydrogenase, alcohol dehydrogenase, superoxide dismutase, catalase, peroxidase and endo- $\beta$-mannanase. The highest values of germination and vigor were found in seeds harvested at $45 \mathrm{DAA}$ and $45 \mathrm{DAAr}$, mainly for hybrids $\mathrm{H} 1$ and $\mathrm{H} 2$. The highest values of lipids and proteins and lower carbohydrates were found in the most immature seeds of Jiló. The enzymes analyzed showed higher expression in the initial stages of development, however reduced with the advancement of the maturation stage. Endo- $\beta$-mannanase expression increased with seed development. Jiló seeds harvested at 45 DAAr presented the highest of germination and vigor values. This "being" considered as the ideal harvest point.
\end{abstract}

\section{Keywords}

Seed Quality, Germination, Enzyme, Harvesting Point, Seed Development 


\section{Introduction}

One of the factors that interfere with the seed quality is harvest. Therefore, it is important to know the physiological and biochemical changes that occur during the development of the seeds for the definition of the ideal harvest moment (Abud et al.) [1].

In several studies, even after harvesting some species with fleshy fruits, the seeds continue their ripening in case they have not completed it in the plant. This is advantageous because it reduces the number of harvests, and fruits with different degrees of ripening can be harvested [2] [3].

Originating in Africa and being introduced in Brazil by slaves, the Jiló plant (Solanum gilo Raddi) is a heat-demanding tropical vegetable. It belongs to the Solanaceae family, and its fruits are light green or dark green and white when unripe, becoming orange and reddish when ripe [4].

Jiló is a vegetable of great acceptance in the Brazilian market, mainly in the southeast region. The production and marketing of Jiló have expanded to other countries, where Brazilian immigration is high. The example of this is the State of Massachusetts, in the United States, where there was an incentive to produce vegetables not previously commercialized there, such as Jiló, Taioba and Maxixe [5].

Although the Jilo plant is cultivated in several regions, research related to the production and technology of seeds inherent to this culture are restricted. It is known that the use of high quality seeds is essential for the establishment of plants in the field and to ensure high productivity [4].

Seed development is characterized by a series of physical, morphological, physiological and biochemical changes that are initiated by fertilization of the ovum [6] [7].

Variations in the environmental conditions to which seeds are subject during maturation and storage may directly interfere with physiological quality causing degenerative metabolic changes, such as delayed germination, reduced seedling growth, solute leaching, changes in enzymatic activity and loss of cell compartmentalization, factors that characterize seed deterioration and, consequently, lead to problems in crop productivity [8].

Due to the demand for high quality seeds, it is essential to know the seed formation processes in order to determine the ideal harvest time.

By means of studies related to the development of seeds, it is possible to determine the point at which the seed is disconnected from the mother plant, without prejudice to its physiological quality, as well as to determine the moment of harvest.

However, generally, further studies about Jiló are still necessary, mainly in the seeds area [9]. In this context, the objective of this research was to evaluate the physiological quality of Jiló seeds during development through physiological, biochemical and electrophoretic tests of enzymes.

Through studies involving the development of Jiló seeds through physiologi- 
cal and biochemical analyzes, as in this research, it will be possible to determine both harvest point and physiological maturity.

\section{Materials and Methods}

\subsection{Place of Seed Collection}

The experiment was carried out from July 2014 to April 2015. Research was carried out at the Center for Development and Technology Transfer/at the Hortiagro Seeds Company Ltd., Municipality of Ijaci, Minas Gerais, and at the Central Seed Laboratory of the Department of Agriculture of the Federal University of Lavras (UFLA).

At the first stage of the study, in a greenhouse at $25^{\circ} \mathrm{C}$ to $30^{\circ} \mathrm{C}$ and irrigation was done daily, Jiló seedlings were formed for the implementation of the experiment and seed production. The seeds were sowed on commercial substrates in 128-cell trays. When the seedlings presented four ultimate leaves, they were transplanted to the field.

During the flowering stage, after emasculation and manual pollination for hybrids production, flowers were labeled daily on the anthesis day until the fruit number was reached, which guaranteed enough seeds for all analyses of each treatment.

Four commercial genetic materials, JIL 001, JIL 006, JIL white and cultivar JIL 005 (pollen donor) and two hybrids $\mathrm{H} 1$ and $\mathrm{H} 2$, from the crosses between JIL

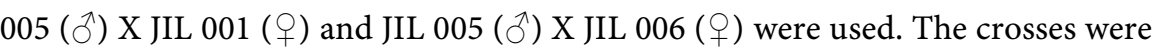
carried out manually, after the emasculation of the female parental.

Fruit harvesting was performed at 35, 40, and 45 days after anthesis (DAA) of the first flowering. A total of $50 \%$ of the fruits harvested at $45 \mathrm{DAA}$ were put to rest for seven days (45 DAAr) in a cool and ventilated place, totaling 24 treatments (six genetic materials and four stages of fruit development).

The experiment was set up in a randomized block design (RBD) with 24 treatments and three replications, where each plot was composed of 1 row of 6 meters long with 10 plants, spaced 1 meter between rows and $0.60 \mathrm{~m}$ between plants.

\subsection{Laboratory Experiments}

The seed quality evaluation was carried out at the Central Seed Laboratory of the Federal University of Lavras (UFLA) Department of Agriculture, in Lavras, MG.

After the manual extraction, the water content of the seeds was evaluated. Seeds submitted to the different treatments were dried in an air circulation oven at $35^{\circ} \mathrm{C}$ up to approximately $8 \%$ water content.

\subsection{Water Content}

The water content of the seeds was determined prior to the installation of the experiments by the stove method at $105^{\circ} \mathrm{C}$ for 24 hours, using two 1 gram sub-samples for each treatment, according to the Rules for Seed Analysis (RSA) 
[10]. The results were expressed as a percentage.

\subsection{Weight of a Thousand Seeds}

The weight of a thousand seeds was calculated by weighing 8 replicates of 100 dried seeds ( $8 \%$ moisture) of each treatment, using a scale with three decimal places accuracy [10].

\subsection{Electrical Conductivity}

The electrical conductivity test was carried out in the mass system with eight replicates of 50 seeds, which were weighed to two decimal places precision and then placed in disposable plastic cups with $25 \mathrm{~mL}$ of distilled water. After 24 hours of soaking in deionized water at $25^{\circ} \mathrm{C}$, the electrical conductivity was determined using a conductivity meter (Digimed ${ }^{\circledast}$ ) with results expressed in $\mu \mathrm{S} \cdot \mathrm{cm}^{-1} \cdot \mathrm{g}^{-1}$, according to the method described by Torres and Pereira [11].

\subsection{Germination}

The germination tests were carried out with eight replicates of 50 seeds, sown on two sheets of blotting paper, moistened with water in the proportion of 3 times the weight of the dry substrate, in gerbox plastic boxes.

The seeds were kept in alternating temperature and light germinating chambers at $20^{\circ} \mathrm{C} / 16$ hours in the dark and $30^{\circ} \mathrm{C} / 8$ hours in the presence of light. The evaluations were carried out at 7 and 14 days after sowing [10].

The results were expressed as percentage of normal seedlings for germination. For calculations of the germination speed index, daily readings of the number of normal and protruding roots, respectively, were taken. The calculation was made according to Maguire [12].

\subsection{Seedling Emergence}

For the seedling emergence, four replicates of 50 seeds were used, which were sowed on commercial substrate placed in polystyrene trays of 128 cells. The trays were kept in a greenhouse at $25^{\circ} \mathrm{C}$ to $30^{\circ} \mathrm{C}$ and irrigation was done daily.

Daily evaluations were also performed from the beginning of the emergence, computing the number of normal seedlings with cotyledon leaves above the soil up to 14 days. For the emergence speed index, the calculations were made according Maguire [12].

\subsection{Chemical Composition of Seeds}

Determination of the chemical composition for the lipid, carbohydrates and protein composition was performed with three replicates of each treatment according to AOAC [13].

\subsection{Enzymatic Analyzes}

Enzymatic Analyzes were analyzed the enzymes: EST, esterase, (carboxylic-ester 
hydrolase, EC 3.1.1.1); ISO, isocitrate lyase (isocitrate glyoxylate-lyase (succinate-forming), EC 4.1.3.1); SOD, superoxide dismutase (superoxide: superoxide oxidoreductase, EC 1.15.1.1); POX, Peroxidase (phenolic donor: hydrogen-peroxide oxidoreductase, EC 1.11.1.7); CAT, Catalase (hydrogen-peroxide oxidoreductase, EC 1.11.1.6); $\mathrm{ADH}$, alcohol dehydrogenase (alcohol: $\mathrm{NAD}^{+}$oxidoreductase, EC 1.11.1.1); $\mathrm{MDH}$, malate dehydrogenase (( $S)$-malate: $\mathrm{NAD}^{+}$oxidoreductase, EC 1.1.1.37) e da endo- $\beta$-mannanase (Mannan endo-1,4-beta-mannosidase, EC 3.2.1.78).

For electrophoretic analysis of enzymes, the seeds were ground in the presence of PVP and liquid nitrogen in porcelain crucible on ice and later stored at $-86^{\circ} \mathrm{C}$.

For enzyme extraction, $0.2 \mathrm{M}$ Tris HCL buffer $\mathrm{pH} 8.0+(0.1 \%$ mercaptoethanol) was used in the proportion of $250 \mu \mathrm{L}$ per $100 \mathrm{mg}$ of seeds. The material used was vortex, duly homogenized and held overnight in the refrigerator, followed by centrifugation at $14,000 \mathrm{rpm}$ for 60 minutes at $4^{\circ} \mathrm{C}$. The electrophoretic run occurred in a $7.5 \%$ polyacrylamide gel system (separator gel) and $4.5 \%$ (concentrator gel). The gel/electrode system used was Tris-glycine $\mathrm{pH}$ 8.9. A total of 50 $\mu \mathrm{L}$ of the supernatant of the samples was applied to the gel and the electrophoretic run performed at $120 \mathrm{~V}$ for 5 hours.

At the end of the run, the gels were revealed for the enzymes catalase, esterase, peroxidase, superoxide dismutase, alcohol dehydrogenase, malate dehydrogenase, isocitrate lyase, and endo- $\beta$-mannanase according to Alfenas [14].

After obtaining the gels, the enzyme images were quantified with the help of the Image ${ }^{\oplus}$ program in the squared millimeter unit $\left(\mathrm{mm}^{2}\right)$.

\section{Design and Statistical Analysis}

The experimental design used in the tests for the evaluation of the quality of Jilo seeds was in $6 \times 4$ factorial scheme, whose factors were six genetic materials and four harvest seasons. Variance analysis ANOVA was performed for all the tests, using Sisvar 5.6 statistical software [15]. For comparison between means, the Scott-Knott [16] was used, at 5\% probability.

\section{Results and Discussion}

\subsection{Water Content}

The water content of the seeds was reduced during seed development (Figure 1). It is important to emphasize that the water content of the seeds at different stages of development did not vary much when comparing the different genetic materials used.

The high water content in the initial phase of maturation required for cell expansion, translocation of compounds and their subsequent decrease during maturation is related to the importance of water in the seed formation processes. During the development phase, the water content of the seed remains high; there is intense accumulation of dry matter, represented by proteins, sugars, lipids and other substances until they reach physiological maturity. 


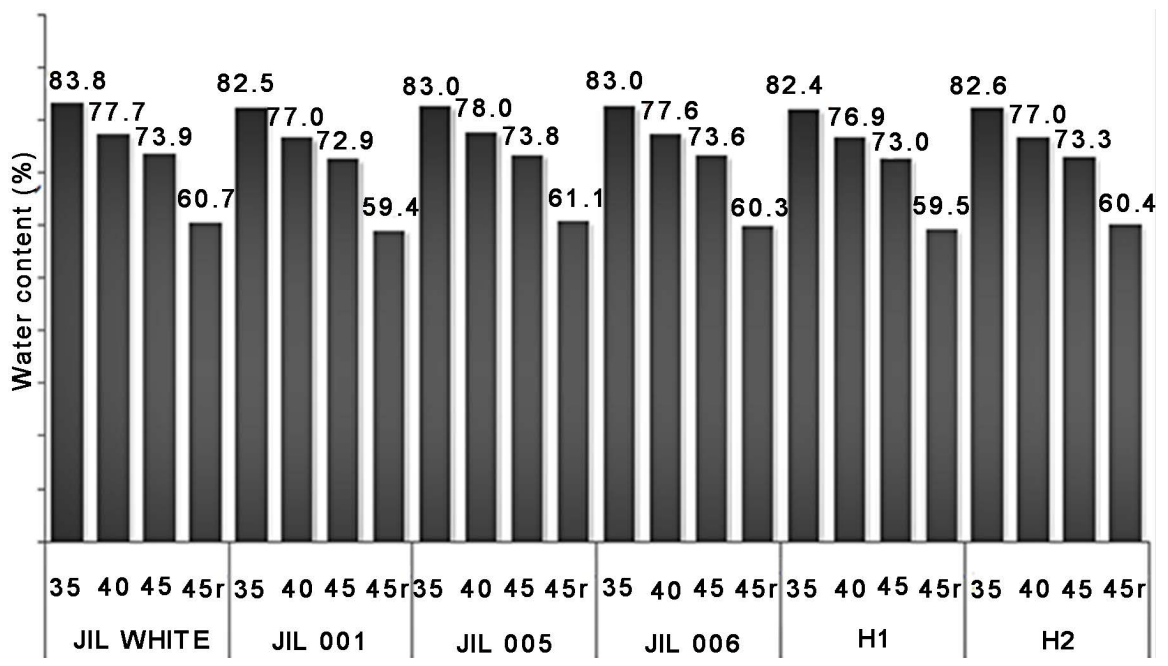

Figure 1. Water content in Jiló seeds of each treatment when harvested at different stages of development.

At the point of physiological maturity when the translocation of photoassimilates to the seeds ceases, the water content decreases as the water is replaced by the synthesized reserves [17] [18] [19].

\subsection{Weight of One Thousand Seeds}

The weight of one thousand seeds from fruits harvested at 45 DAAr was statistically higher than that found in seeds harvested at the other stages of development, except for the seeds of hybrids $\mathrm{H} 1$ and $\mathrm{H} 2$ where there was no statistical difference in these values at $45 \mathrm{DAA}$ and 45 DAAr. There was a progressive increase in the weight of a thousand seeds, with maturation progress, with a more significant difference between the values obtained at 35 and 45 DAA (Table 1).

However, the weight gain in seeds harvested at 45 DAAr in relation to the seeds extracted at $45 \mathrm{DAA}$, in absolute values, was lower in seeds harvested at the other stages of maturation, the seeds harvested at 45 DAAr had reached physiological maturity. However, during the rest period, there was an increase in the dry weight of seeds.

This variation in weight can be attributed to the translocation of photoassimilates from the fruits to the seeds since they were disconnected from the plant.

The lowest weight values of one thousand seeds were found in white (JIL white) seeds harvested at different maturation stages, and the highest values were found in seeds of hybrids $\mathrm{H} 1$ and $\mathrm{H} 2$.

Exception was found at $40 \mathrm{DAA}$, where there were lower values in white Jiló (JIL white) seeds and higher in seeds of the other genetic materials.

Similar results were found with cucumber seeds (Cucumis sativus L.) by Nakada et al. [20], where higher values of the weight of a thousand seeds were found between the stages of 45 and 50 days after anthesis.

According to Carvalho and Nakagawa [17] the more distant from the anthesis the seeds are removed from the fruits, the heavier the seeds will be until their 
Table 1. Weight of one thousand seeds ( $\mathrm{g}$ ) of seeds obtained from Jiló fruits.

\begin{tabular}{ccccc}
\hline \multicolumn{5}{c}{ Weight of a thousand seeds (g) } \\
\hline Genetic material & $35 \mathrm{DAA}$ & $40 \mathrm{DAA}$ & $45 \mathrm{DAA}$ & $45 \mathrm{DAAr}$ \\
H1 & $1.87 \mathrm{cA}$ & $2.11 \mathrm{bA}$ & $2.37 \mathrm{aA}$ & $2.48 \mathrm{aA}$ \\
H2 & $1.61 \mathrm{cB}$ & $2.14 \mathrm{bA}$ & $2.47 \mathrm{aA}$ & $2.55 \mathrm{aA}$ \\
JIL 001 & $1.55 \mathrm{~dB}$ & $2.01 \mathrm{cB}$ & $2.16 \mathrm{bB}$ & $2.33 \mathrm{aB}$ \\
JIL 005 & $1.55 \mathrm{~dB}$ & $1.94 \mathrm{cB}$ & $2.15 \mathrm{bB}$ & $2.32 \mathrm{aB}$ \\
JIL 006 & $1.57 \mathrm{~dB}$ & $2.09 \mathrm{cA}$ & $2.29 \mathrm{bB}$ & $2.36 \mathrm{aB}$ \\
JIL WHITE & $0.96 \mathrm{dC}$ & $1.49 \mathrm{cC}$ & $1.83 \mathrm{bC}$ & $2.00 \mathrm{aC}$ \\
CV & & & \\
\hline
\end{tabular}

Averages followed by the same letter, uppercase and lowercase in the rows, do not differ from one another by the Scott-Knott Test at $5 \%$ probability. ${ }^{1}$ coefficient of variation.

physiological maturity. Miranda et al. [21] studied the maturation of eggplant fruits, and reported that there was no difference in dry weight gain between seeds harvested at $50 \mathrm{DAA}$ in relation to seeds harvested at $60 \mathrm{DAA}$. Oliveira et al. [22] reported that at $55 \mathrm{DAA}$, the pepper seeds had reached physiological maturity, being the point where they reached higher weight, coinciding with the best time to harvest.

\subsection{Electrical Conductivity}

The electrical conductivity values of the seeds were reduced with maturation, indicating an increase in seed vigor (Table 2). The electrical conductivity values of seeds harvested at 35 DAA were the highest and the lowest were found in seeds of fruits harvested at $45 \mathrm{DAA}$, which were at rest for seven days (45 DAAr). The fruit seeds harvested at $45 \mathrm{DAA}$, and which remained at rest for seven days, probably had more organized membrane systems.

At $35 \mathrm{DAA}$, the seeds were more immature, suggesting a disorganization of cell membranes, which favored higher solute leaching. With advancement in maturation stages, the cell membrane systems were organized restricting leaching of solutes.

There were variations of the values of electrical conductivity in seeds of the different genetic materials, harvested at different stages of maturation. The values of electrical conductivity vary according to the different genotypes. Thus, it is difficult to compare the vigor between these different genotypes.

This has been found in other studies when evaluating vigor through this test, since there are other factors inherent to seeds also associated with vigor. Caixeta et al. [23], Pereira et al. [24], found a lower physiological potential in habanero pepper seeds, as well as higher values of conductivity in immature seeds.

According to Martins et al. [25], there is a possibility that the cell membrane protection system will be inefficient in the early stages of development when the membranes are not well structured yet. 
Table 2. Electric conductivity $\left(\mu \mathrm{S} \cdot \mathrm{cm}^{-1} \cdot \mathrm{g}^{-1}\right)$ of seeds from Jiló fruits.

\begin{tabular}{clcrl}
\hline \multicolumn{5}{c}{ Electrical conductivity $\left(\mu \mathrm{S} \cdot \mathrm{cm}^{-1} \cdot \mathrm{g}^{-1}\right)$} \\
\hline Genetic material & $35 \mathrm{DAA}$ & $40 \mathrm{DAA}$ & $45 \mathrm{DAA}$ & $45 \mathrm{DAAr}$ \\
\hline H1 & $29.07 \mathrm{dA}$ & $18.49 \mathrm{cA}$ & $14.32 \mathrm{bA}$ & $11.69 \mathrm{aA}$ \\
H2 & $64.24 \mathrm{dC}$ & $21.34 \mathrm{cB}$ & $18.60 \mathrm{bB}$ & $16.00 \mathrm{aB}$ \\
JIL 001 & $28.21 \mathrm{dA}$ & $20.15 \mathrm{cB}$ & $17.50 \mathrm{bB}$ & $15.04 \mathrm{aB}$ \\
JIL 005 & $54.96 \mathrm{~dB}$ & $31.84 \mathrm{cC}$ & $23.96 \mathrm{bD}$ & $19.97 \mathrm{aD}$ \\
JIL 006 & $52.90 \mathrm{~dB}$ & $31.56 \mathrm{cC}$ & $26.19 \mathrm{bE}$ & $18.56 \mathrm{aC}$ \\
JIL WHITE & $52.60 \mathrm{~dB}$ & $36.16 \mathrm{cD}$ & $21.90 \mathrm{bC}$ & $17.85 \mathrm{aC}$ \\
CV $1 \%)$ & & &
\end{tabular}

Averages followed by the same letter, uppercase and lowercase in the rows, do not differ from one another by the Scott-Knott Test at $5 \%$ probability. ${ }^{1}$ coefficient of variation.

\subsection{1st Germination Count}

The highest values of germination of Jilo seeds evaluated in the first count, at 7 days, were superior for seeds of fruits harvested at 45 DAAr. There was no germination of harvested seeds at $35 \mathrm{DAA}$, regardless of the genetic material. In seeds harvested at $45 \mathrm{DAAr}$, the highest percentage of germination was in $\mathrm{H} 1$ and $\mathrm{H} 2$ seeds. In later stages of maturation, $45 \mathrm{DAA}$ and $45 \mathrm{DAAr}$, there were lower germination values in white JIL seeds (Table 3 ).

\subsection{Germination and Germination Rate Index}

The percentage of germination and the germination rate index, evaluated at the second count, at 14 days, from seeds harvested at 45 DAA and resting for seven days (45 DAAr), were statistically higher than from that of seeds of fruits harvested at the other maturation stages, considering the genetic material JIL 001, JIL 005, JIL 006 and JIL white. In hybrid seeds $\mathrm{H} 1$ and H2, there was no statistical difference of these values in seeds harvested at $45 \mathrm{DAA}$, regardless of their submission to rest.

Among the genetic materials, there was no statistical difference in the germination and seed germination rates of the fruits harvested at $45 \mathrm{DAAr}$.

In seeds of fruits harvested at initial stages of development, at 35 and 40 DAA, the germination and germination speed values were significantly lower than the values found at later stages of maturation, at 45 DAA and 45 DAAr (Table 4 and Table 5).

In hybrid seeds ( $\mathrm{H} 1$ and $\mathrm{H} 2)$, there were higher germination values when they were extracted from fruits at less advanced stages of maturation, 35, 40 and 45 DAA. The higher vigor of hybrid seeds at less advanced maturation stages was also found by the Germination speed index test in seeds harvested at 35 and 45 DAA.

\subsection{Emergence and Emergence Speed Index}

The emergence percentage and the emergence speed index of seedlings from fruit seeds harvested at 45 DAAr were statistically higher than those in seeds 
Table 3. First seed germination count from Jiló fruits.

\begin{tabular}{ccccc}
\hline \multicolumn{5}{c}{$1^{\text {st }}$ Germination count (\%) } \\
\hline Genetic material & 35 DAA & 40 DAA & 45 DAA & 45 DAAr \\
\hline H1 & $0 \mathrm{dA}$ & $5 \mathrm{cA}$ & $31 \mathrm{bB}$ & $45 \mathrm{aB}$ \\
H2 & $0 \mathrm{dA}$ & $6 \mathrm{cA}$ & $43 \mathrm{bA}$ & $50 \mathrm{aA}$ \\
JIL 001 & $0 \mathrm{dA}$ & $5 \mathrm{bA}$ & $9 \mathrm{bD}$ & $36 \mathrm{aC}$ \\
JIL 005 & $0 \mathrm{dA}$ & $4 \mathrm{cA}$ & $8 \mathrm{bD}$ & $37 \mathrm{aC}$ \\
JIL 006 & $0 \mathrm{dA}$ & $3 \mathrm{cB}$ & $11 \mathrm{bC}$ & $37 \mathrm{aC}$ \\
JIL WHITE & $0 \mathrm{cA}$ & $2 \mathrm{bB}$ & $4 \mathrm{bE}$ & $26 \mathrm{aD}$ \\
CV & & &
\end{tabular}

Averages followed by the same letter, uppercase and lowercase in the rows, do not differ from one another by the Scott-Knott Test at $5 \%$ probability. ${ }^{1}$ coefficient of variation.

Table 4. Germination of seeds from Jiló fruits.

\begin{tabular}{ccccc}
\hline \multicolumn{5}{c}{ Germination (\%) } \\
\hline Genetic material & 35 DAA & 40 DAA & 45 DAA & 45 DAAr \\
\hline H1 & $23 \mathrm{cA}$ & $42 \mathrm{bA}$ & $100 \mathrm{aA}$ & $100 \mathrm{aA}$ \\
H2 & $18 \mathrm{cB}$ & $34 \mathrm{bB}$ & $99 \mathrm{aA}$ & $100 \mathrm{aA}$ \\
JIL 001 & $12 \mathrm{dC}$ & $26 \mathrm{cC}$ & $91 \mathrm{bB}$ & $100 \mathrm{aA}$ \\
JIL 005 & $10 \mathrm{dC}$ & $27 \mathrm{cC}$ & $73 \mathrm{bC}$ & $100 \mathrm{aA}$ \\
JIL 006 & $7 \mathrm{dD}$ & $29 \mathrm{cC}$ & $88 \mathrm{bB}$ & $100 \mathrm{aA}$ \\
JIL WHITE & $4 \mathrm{dD}$ & $22 \mathrm{cD}$ & $87 \mathrm{bB}$ & $97 \mathrm{aA}$ \\
CV $^{1}(\%)$ & & 7.88 & & \\
\hline
\end{tabular}

Averages followed by the same letter, uppercase and lowercase in the rows, do not differ from one another by the Scott-Knott Test at 5\% probability. ${ }^{1}$ coefficient of variation.

Table 5. Germination speed index (GSI) of seeds from Jiló fruits.

\begin{tabular}{ccccc}
\hline \multicolumn{5}{c}{ Germination speed index (\%) } \\
\hline Genetic material & $35 \mathrm{DAA}$ & $40 \mathrm{DAA}$ & $45 \mathrm{DAA}$ & $45 \mathrm{DAAr}$ \\
\hline H1 & $2.0 \mathrm{cA}$ & $3.0 \mathrm{bA}$ & $7.0 \mathrm{aA}$ & $7.0 \mathrm{aA}$ \\
H2 & $2.0 \mathrm{cA}$ & $2.2 \mathrm{bB}$ & $7.0 \mathrm{aA}$ & $7.0 \mathrm{aA}$ \\
JIL 001 & $1.0 \mathrm{cB}$ & $2.0 \mathrm{cB}$ & $6.0 \mathrm{bB}$ & $7.0 \mathrm{aA}$ \\
JIL 005 & $0.6 \mathrm{dC}$ & $1.9 \mathrm{cB}$ & $6.0 \mathrm{bB}$ & $7.0 \mathrm{aA}$ \\
JIL 006 & $0.4 \mathrm{dC}$ & $2.0 \mathrm{cB}$ & $6.0 \mathrm{bB}$ & $7.0 \mathrm{aA}$ \\
JIL WHITE & $0.1 \mathrm{dC}$ & $2.0 \mathrm{cB}$ & $5.0 \mathrm{bC}$ & $6.8 \mathrm{aA}$ \\
CV ${ }^{1}(\%)$ & & & \\
\hline
\end{tabular}

Averages followed by the same letter, uppercase and lowercase in the rows, do not differ from one another by the Scott-Knott Test at $5 \%$ probability. ${ }^{1}$ coefficient of variation. 
harvested at the other stages. It should be noted that the highest values of emergence and emergence speed were found in seeds of hybrids $\mathrm{H} 1$ and $\mathrm{H} 2$.

In seeds harvested at the early stages of development, at 35 and $40 \mathrm{DAA}$, there was no emergence of seedlings or it occurred with low values of emergence, respectively.

As it can be seen, seed vigor increased as the maturation process progressed. At $45 \mathrm{DAA}$, the average percentage of emergence was $86 \%$, and for the $45 \%$ treatment, 95\%, as shown in (Table 6 and Table 7).

In Jilo seeds, the emergence percentage was $100 \%$ of both hybrids, when they were extracted from fruits with 45 days after the anthesis and submitted to rest. It should be emphasized that in the seeds submitted to this same JIL white genetic material treatment, the lowest values of vigor were found, evaluated by means of these tests.

Seeds with high vigor have a well-structured membrane system and the whole apparatus is ready for germination, which is directly related to the germination speed [18].

Table 6. Emergence of seedlings from Jiló fruits.

\begin{tabular}{ccccc}
\hline \multicolumn{5}{c}{ Emergence (\%) } \\
\hline Genetic material & $35 \mathrm{DAA}$ & $40 \mathrm{DAA}$ & $45 \mathrm{DAA}$ & $45 \mathrm{DAAr}$ \\
\hline H1 & $0 \mathrm{dA}$ & $53 \mathrm{cA}$ & $92 \mathrm{bA}$ & $100 \mathrm{aA}$ \\
H2 & $0 \mathrm{dA}$ & $54 \mathrm{cA}$ & $95 \mathrm{bA}$ & $100 \mathrm{aA}$ \\
JIL 001 & $0 \mathrm{dA}$ & $36 \mathrm{cB}$ & $75 \mathrm{bD}$ & $89 \mathrm{aC}$ \\
JIL 005 & $0 \mathrm{dA}$ & $35 \mathrm{cB}$ & $87 \mathrm{bB}$ & $95 \mathrm{aB}$ \\
JIL 006 & $0 \mathrm{dA}$ & $34 \mathrm{cB}$ & $81 \mathrm{bC}$ & $95 \mathrm{aB}$ \\
JIL WHITE & $0 \mathrm{dA}$ & $17 \mathrm{cC}$ & $84 \mathrm{bC}$ & $89 \mathrm{aC}$ \\
CV ${ }^{1}(\%)$ & & & \\
\hline
\end{tabular}

Averages followed by the same letter, uppercase and lowercase in the rows, do not differ from one another by the Scott-Knott Test at $5 \%$ probability. ${ }^{1}$ coefficient of variation.

Table 7. Emergence speed index (ESI) of seedlings from Jiló fruits

\begin{tabular}{ccccc}
\hline \multicolumn{5}{c}{ ESI (\%) } \\
\hline Genetic material & $35 \mathrm{DAA}$ & $40 \mathrm{DAA}$ & $45 \mathrm{DAA}$ & $45 \mathrm{DAAr}$ \\
\hline H1 & $0 \mathrm{dA}$ & $2.1 \mathrm{cB}$ & $4.0 \mathrm{bB}$ & $5.0 \mathrm{aA}$ \\
H2 & $0 \mathrm{dA}$ & $2.5 \mathrm{cA}$ & $4.0 \mathrm{bA}$ & $5.0 \mathrm{aA}$ \\
JIL 001 & $0 \mathrm{dA}$ & $1.4 \mathrm{cC}$ & $3.4 \mathrm{Bc}$ & $4.7 \mathrm{aB}$ \\
JIL 005 & $0 \mathrm{dA}$ & $1.4 \mathrm{cC}$ & $4.0 \mathrm{bB}$ & $4.7 \mathrm{aB}$ \\
JIL 006 & $0 \mathrm{dA}$ & $1.3 \mathrm{cC}$ & $4.0 \mathrm{Bb}$ & $4.8 \mathrm{aB}$ \\
JIL WHITE & $0 \mathrm{dA}$ & $0.7 \mathrm{cD}$ & $3.4 \mathrm{Bc}$ & $4.2 \mathrm{aC}$ \\
CV $1 \%)$ & & 7.14 & \\
\hline
\end{tabular}

Averages followed by the same letter, uppercase and lowercase in the rows, do not differ from one another by the Scott-Knott Test at $5 \%$ probability. ${ }^{1}$ coefficient of variation. 
At the physiological maturity, the seeds reach the maximum germination and vigor, due to the complete formation of the biochemical, morphological and structural systems, according to Silva et al. [26], Nakada et al. [20].

In the case of seeds with fleshy fruits, such as Jiló, the maximum germination, vigor and dry matter accumulation levels occur when the seeds reach physiological maturity, according to Nascimento and Freitas [3].

According to studies on the maturation of pepper fruits [26], early harvests cause losses to the physiological quality of the seeds, impairing germination and emergence.

In a study conducted by Castro [27] with the Morro Grande Jiló cultivar, there was an increase in the percentage values in the first germination count, germination and germination speed index as a function of the different fruit harvest points. In the same study, an improvement in the physiological quality of Jilo seeds from fruits that remained at rest for 14 days after harvest was also reported.

Pereira et al. [24], in a study carried out with chili seeds from fruits harvested at different maturation stages, and which remained for seven days at rest, found higher values of germination, emergence, and emergence speed index.

Similar results as for the gradual increase in the percentages of germination, emergence and germination speed in the different stages of maturation were found for the green pepper [22], Jilo [27], cucumber (Cucumis sativus L.) [20], green pepper; pumpkin [28], pepper (Capsicum baccatum L.) [23] [24], (Capsicum chinense JACQUIM) [29], Capsicum baccatum var. pendulum [30].

In general for all physiological tests there were significant genotype $\times$ harvest time interactions, where the hybrids had the highest results from $45 \mathrm{DAA}$ and with maximum values at $45 \mathrm{DAAr}$ for all the genetic materials studied. However, JIL BRANCO presented, in general, the lowest values, demonstrating to have inferior physiological quality with the other genetic materials.

\section{Chemical Composition of Jiló Seeds}

\subsection{Lipids, Carbohydrates and Protein}

The chemical composition of Jiló seeds during maturation stages $(35,40,45$ DAA and 45 DAAr) varied in relation to lipid, carbohydrate and protein contents.

During seed development for all treatments, lipid content was generally reduced, with the highest values found at $35 \mathrm{DAA}$, and reduced in seeds harvested at later stages of maturation. For the other genetic materials, there was an important variation of lipid contents in seeds at different maturation stages (Table 8).

Lipids are considered energy sources, more efficient than carbohydrates, during germination and may also have a reserve and structural function. In this way, it is inferred that the lipids, present in the most immature seeds, have been used as energy source during the development process in the maturation stages. 
Table 8. Lipid contents in Jiló seeds from fruits.

\begin{tabular}{ccccc}
\hline \multicolumn{5}{c}{ Lipids (\%) } \\
\hline Genetic material & $35 \mathrm{DAA}$ & $40 \mathrm{DAA}$ & $45 \mathrm{DAA}$ & $45 \mathrm{DAAr}$ \\
\hline H1 & $8.51 \mathrm{aE}$ & $8.02 \mathrm{aB}$ & $8.10 \mathrm{aB}$ & $4.73 \mathrm{bA}$ \\
H2 & $17.40 \mathrm{aB}$ & $14.28 \mathrm{bA}$ & $5.14 \mathrm{cC}$ & $4.86 \mathrm{cA}$ \\
JIL 001 & $10.70 \mathrm{aD}$ & $7.66 \mathrm{bB}$ & $5.08 \mathrm{cC}$ & $5.13 \mathrm{cA}$ \\
JIL 005 & $14.06 \mathrm{aC}$ & $8.43 \mathrm{bB}$ & $7.45 \mathrm{cB}$ & $2.21 \mathrm{~dB}$ \\
JIL 006 & $17.36 \mathrm{aB}$ & $8.32 \mathrm{bB}$ & $7.56 \mathrm{cA}$ & $4.00 \mathrm{dA}$ \\
JIL WHITE & $20.66 \mathrm{aA}$ & $14.43 \mathrm{bA}$ & $8.88 \mathrm{cA}$ & $4.73 \mathrm{dA}$ \\
CV $1 \%)$ & & & \\
\hline
\end{tabular}

Averages followed by the same letter, uppercase and lowercase in the rows, do not differ one another by the Scott-Knott Test at $5 \%$ probability. ${ }^{1}$ coefficient of variation.

The organization of lipoprotein membranes directly affects the normality of physiological processes in seeds, such as germination, dormancy, vigor manifestation, desiccation tolerance and physiological conditioning [18].

The carbohydrate contents, in general, increase with the advance of the process of seed maturation, independently of the genetic material used.

The highest values of carbohydrates were found in seeds extracted from Jiló fruits that were harvested at 45 DAAr. There was a significant variation of the carbohydrate contents between the seeds of the different genetic material. At the beginning of the seed development process, 35 and 40 DAA lower carbohydrate values were found in JIL white seeds and higher in H1 seeds (Table 9).

In general, protein content in Jilo seeds was reduced in seeds subject to 45 DAAr treatment (45 DAA rested for seven days) in relation to the seeds harvested at 35 DAA, except for the values found for genetic material JIL 001, (Table $10)$.

The development of most seeds can be divided into three confluent phases: initial embryo growth (embryogenesis); accumulation of reserves, with compound synthesis such as starch, proteins and lipids (intermediate maturation stage); and seed dehydration (development termination). In the accumulation phase of reserves, the embryo presents high germinative potential.

During seed maturation, protection mechanisms are initiated to preserve the integrity of the cellular components when water is removed during drying [19]. At the end of the development, the seeds enter a state of rest, which allows their survival in different environmental conditions [31] [32] [33].

In the present research, there were important variations in the lipids, carbohydrates and proteins composition during the development of seeds of the genetic materials evaluated. In general, there was an increase in carbohydrate levels, and a reduction in lipid and protein contents with the advancement of seed maturation. These changes are probably associated to the variations also found in the values of germination and vigor of these seeds. 
Table 9. Carbohydrate contents in Jiló seeds from fruits.

\begin{tabular}{ccccc}
\hline & \multicolumn{4}{c}{ Carbohydrate (\%) } \\
\hline Genetic material & 35 DAA & 40 DAA & 45 DAA & 45 DAAr \\
\hline H1 & $43.96 \mathrm{cA}$ & $46.55 \mathrm{bA}$ & $47.91 \mathrm{bA}$ & $51.07 \mathrm{aA}$ \\
H2 & $36.86 \mathrm{dC}$ & $39.49 \mathrm{cB}$ & $49.15 \mathrm{bA}$ & $51.78 \mathrm{aA}$ \\
JIL 001 & $40.76 \mathrm{bB}$ & $41.19 \mathrm{bB}$ & $45.89 \mathrm{aB}$ & $45.87 \mathrm{aB}$ \\
JIL 005 & $34.4 \mathrm{dD}$ & $40.61 \mathrm{cB}$ & $44.44 \mathrm{bB}$ & $51.49 \mathrm{aA}$ \\
JIL 006 & $30.34 \mathrm{cE}$ & $47.16 \mathrm{bA}$ & $45.35 \mathrm{bB}$ & $53.36 \mathrm{aA}$ \\
JIL WHITE & $25.67 \mathrm{dF}$ & $37.23 \mathrm{cD}$ & $43.37 \mathrm{bB}$ & $48.12 \mathrm{aB}$ \\
CV & & & \\
\hline
\end{tabular}

Averages followed by the same letter, uppercase and lowercase in the rows, do not differ from one another by the Scott-Knott Test at $5 \%$ probability. ${ }^{1}$ coefficient of variation.

Table 10. Protein contents in Jiló seeds from fruits.

\begin{tabular}{ccccc}
\hline \multicolumn{5}{c}{ Protein (\%) } \\
\hline Genetic material & $35 \mathrm{DAA}$ & $40 \mathrm{DAA}$ & $45 \mathrm{DAA}$ & $45 \mathrm{DAAr}$ \\
\hline H1 & $16.91 \mathrm{aA}$ & $16.91 \mathrm{aC}$ & $15.80 \mathrm{bB}$ & $15.86 \mathrm{bA}$ \\
H2 & $16.62 \mathrm{aA}$ & $17.03 \mathrm{aC}$ & $15.92 \mathrm{bB}$ & $15.16 \mathrm{cB}$ \\
JIL 001 & $15.45 \mathrm{cC}$ & $18.66 \mathrm{aA}$ & $16.38 \mathrm{bA}$ & $15.86 \mathrm{cA}$ \\
JIL 005 & $16.27 \mathrm{bB}$ & $17.49 \mathrm{aB}$ & $15.16 \mathrm{cC}$ & $14.46 \mathrm{dC}$ \\
JIL 006 & $17.32 \mathrm{aA}$ & $15.80 \mathrm{bD}$ & $16.27 \mathrm{bA}$ & $15.22 \mathrm{cB}$ \\
JIL WHITE & $17.08 \mathrm{aA}$ & $16.38 \mathrm{aD}$ & $16.56 \mathrm{aA}$ & $15.75 \mathrm{bA}$ \\
CV $\left.{ }^{1} \%\right)$ & & & \\
\hline
\end{tabular}

Averages followed by the same letter, uppercase and lowercase in the rows, do not differ from one another by the Scott-Knott Test at $5 \%$ probability. ${ }^{1}$ coefficient of variation.

In a study conducted by Abud et al. [1], in the early stages of seed development, the dry matter mass increased rapidly. These stages are characterized by histodifferentiation, morphogenesis, and synthesis and deposition of reserves, such as carbohydrates, lipids and proteins [19] [34].

\section{Analysis of Enzymatic Expressions}

The results obtained for all expressions of the analyzed isoenzymes showed a significant difference in the different stages of maturation of each genetic material. The highest values of enzymatic expression occurred in the initial stages of maturation (35 and 40 DAA), mainly for the genetic material JIL WHITE. Moreover, the low expressions of isoenzymes occurred in the more advanced stages of maturation (40 and 45 DAAr). Being that the hybrids $\mathrm{H} 1$ and $\mathrm{H} 2$ stood out of the other genetic materials. The results of each enzyme are shown below:

\subsection{Esterase}

By the electrophoretic analysis of the esterase enzyme (EST), the expressions de- 
creased along with the maturation process, (35, 40, 45 DAA and 45 DAAr), in seeds of all genetic materials evaluated (Figure 2).

The highest esterase enzyme (EST) expressions occurred mainly in seeds harvested at the stages of 35, 40 and $45 \mathrm{DAA}$, and the lowest expressions in seeds harvested at $45 \mathrm{DAA}$ and maintained at rest in fruits for seven days. The early harvesting of seeds at the beginning of development (immature), may have contributed to the deterioration process of these and with the consequent increase in isoenzyme esterase (EST) expression at the early stages of maturation.

Results were found by Nakada et al. [20], Queiroz et al. [35] with cucumber and pepper seeds, respectively, where the highest esterase expressions were found at the early maturation stages ( 35 and 35 DAA).

Esterase is an enzyme involved in the hydrolysis of membrane esters. This fact demonstrates higher lipid peroxidation, since this enzyme is involved in ester hydrolysis reactions where it is directly linked to lipid metabolism [36]. Many of these lipids are membrane constituents whose degradation increases with deterioration.

It is important to emphasize that in the early stages of seed development there is a process of differentiation of metabolically active tissues (anabolism). In this phase, there are intense cellular divisions and with a structural system not yet fully formed, mainly the cell membrane system, whose degradation increases with the disorganization of the membrane system. This condition leads to changes in esterase expression (EST) found during the Jiló seed maturation process.

Thus, it is important to note that the highest lipid contents were found in the most immature Jilo seeds. These contents were reduced with the advancement of

$\begin{array}{lllllllllllllllllllllll}1 & 2 & 3 & 4 & 5 & 6 & 7 & 8 & 9 & 10 & 11 & 12 & 13 & 14 & 15 & 16 & 17 & 18 & 19 & 20 & 21 & 22 & 2324\end{array}$

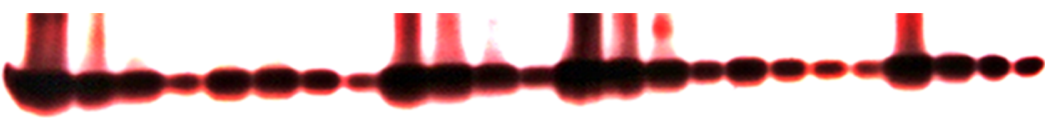

ESTERASE

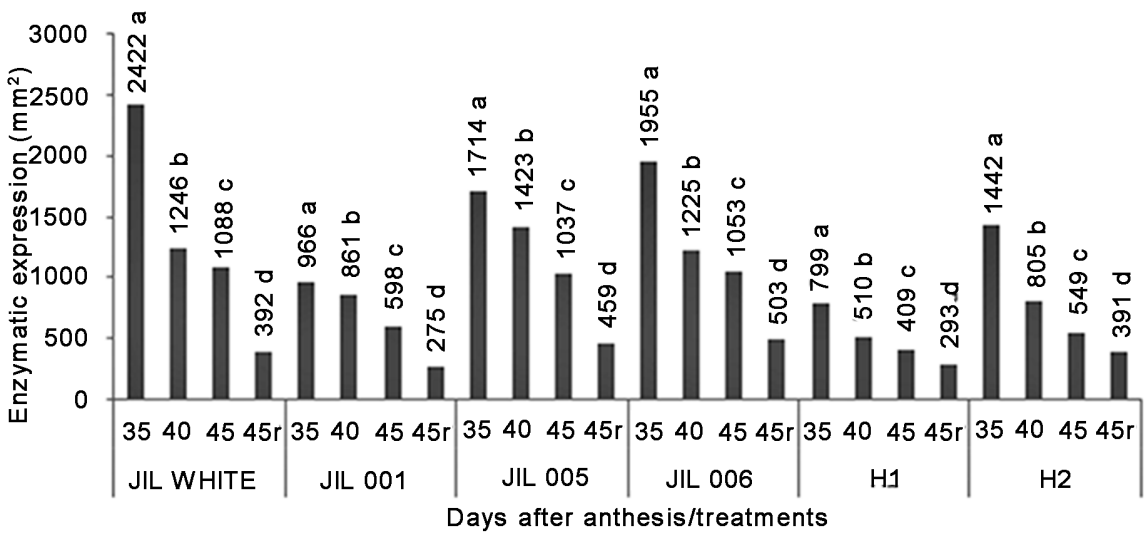

Figure 2. Esterase enzyme (EST) expression of Jiló seeds (JIL white, JIL 001, JIL 005, JIL 006, $\mathrm{H} 1$ and $\mathrm{H} 2)$, harvested at different maturation stages $(35,40,45 \mathrm{DAA}$ and $45 \mathrm{DAAr})$. 
the maturation process, mainly in seeds harvested at $45 \mathrm{DAA}$ and that remained in the fruits for seven days.

Comparing these results with the esterase enzyme expression, the higher the lipid content in seeds, the greater the expression of the esterase enzyme.

Also, lower expression of this enzyme was found in seeds of hybrids ( $\mathrm{H} 1$ and H2) and seeds of cultivar JIL 001, especially when harvested immaturely (35 DAA).

Smaller enzymatic expressions occurred in seeds harvested at $45 \mathrm{DAA}$ and especially in those submitted to 45 DAAr. In latter ones, lower values of electrical conductivity and higher percentages of germination and emergence were also found, in relation to the seeds harvested in less advanced stages of maturation.

\subsection{Isocitrate lyase}

As for esterase (EST), the isocitrate lyase enzyme (ISO) expression decreased in all genetic materials used in this research, with the advancement of the maturation process (35, 40, 45 DAA and 45 DAAr) (Figure 3).

Isocitrate lyase is a key enzyme in regulating the glyoxylate cycle and it is involved in lipid metabolism and the development of activities in glyoxysomes [37].

In addition to the variation of the expression of the enzyme isocitrate lyase in seeds harvested at different stages of maturation, there was variation of the expression of this enzyme in seeds of genetic materials evaluated. The highest expression was found in white (JIL white) seeds, especially those harvested at 35 days after anthesis.
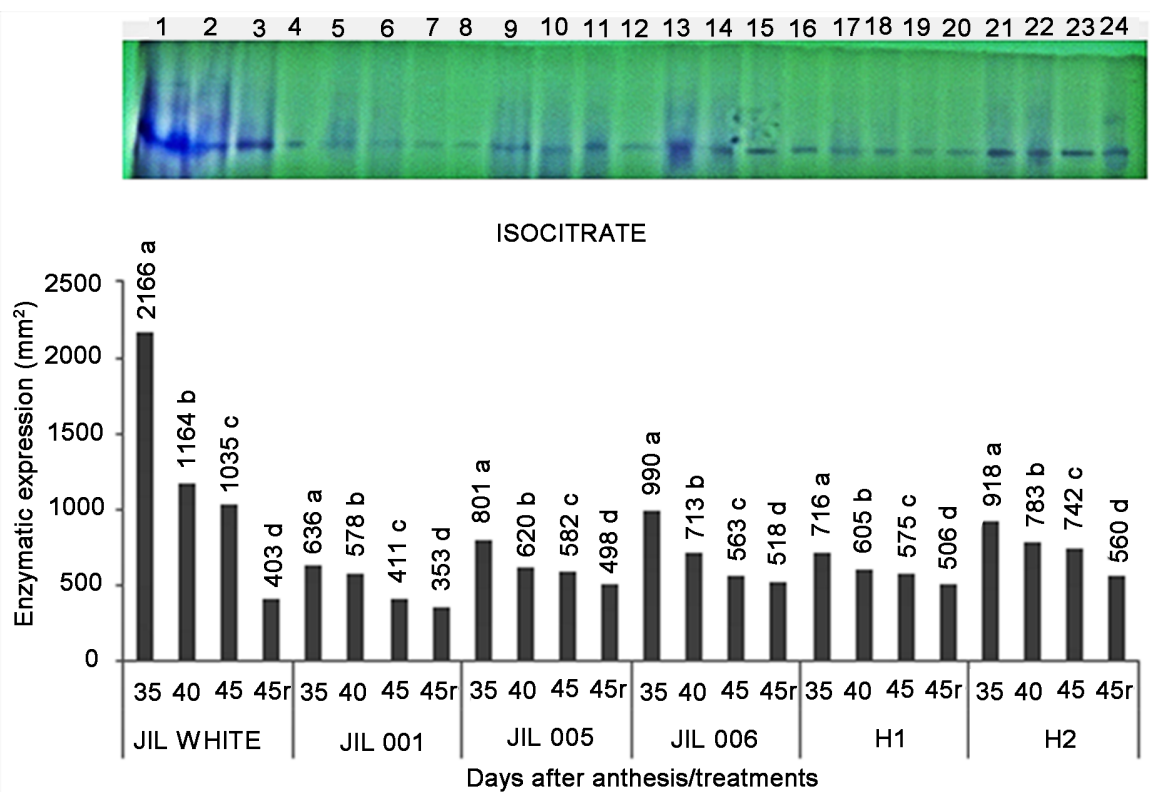

Figure 3. Expressions of the enzyme isocitrate lyase (ISO) of Jilo seeds of the varieties (JIL white, JIL 001, JIL 005, JIL 006, H1 and H2), harvested at different maturation stages $(35,40,45$ DAA and 45 DAAr). 
The greatest isocitrate lyase enzyme expressions are probably associated with the higher lipid levels found in Jilo seeds in the early stages, especially in the initial stages of maturation. Even greater lipid oxidation was found in more immature seeds, reflecting in the process of seed deterioration.

Results were found by Santos et al. [29], where the highest expression of the enzyme isocitrate lyase was found in habanero pepper seeds during the later stages of development.

\subsection{Malate Dehydrogenase}

In relation to the expression of the malate dehydrogenase (MDH) enzyme, there were higher expressions on seeds harvested at $35 \mathrm{DAA}$ in all genetic materials (Figure 4). The expression reduced in more mature seeds, especially when the fruits were harvested at 45 days after anthesis and submitted to rest for seven days (45 DAAr).

Malate dehydrogenase (MDH) plays a significant role in the Krebs cycle, since it catalyzes the conversion of malate to oxaloacetate, producing NADH, which is a key product in the production of ATP and essential intermediate compounds for cell functioning [38].

The interruption of the maturation process due to the anticipation of the harvest probably accelerated the deterioration process and the respiratory rate of the seeds, thus occurring higher expressions of $\mathrm{MDH}$ in seeds from fruits harvested at the initial maturation stages.

During seed development, at the stage where dry matter accumulation is occurring, the water content is maintained at high levels. On the other hand, as the seeds maintain high water content and their dry mass content increases the respiratory intensity also increases [17].
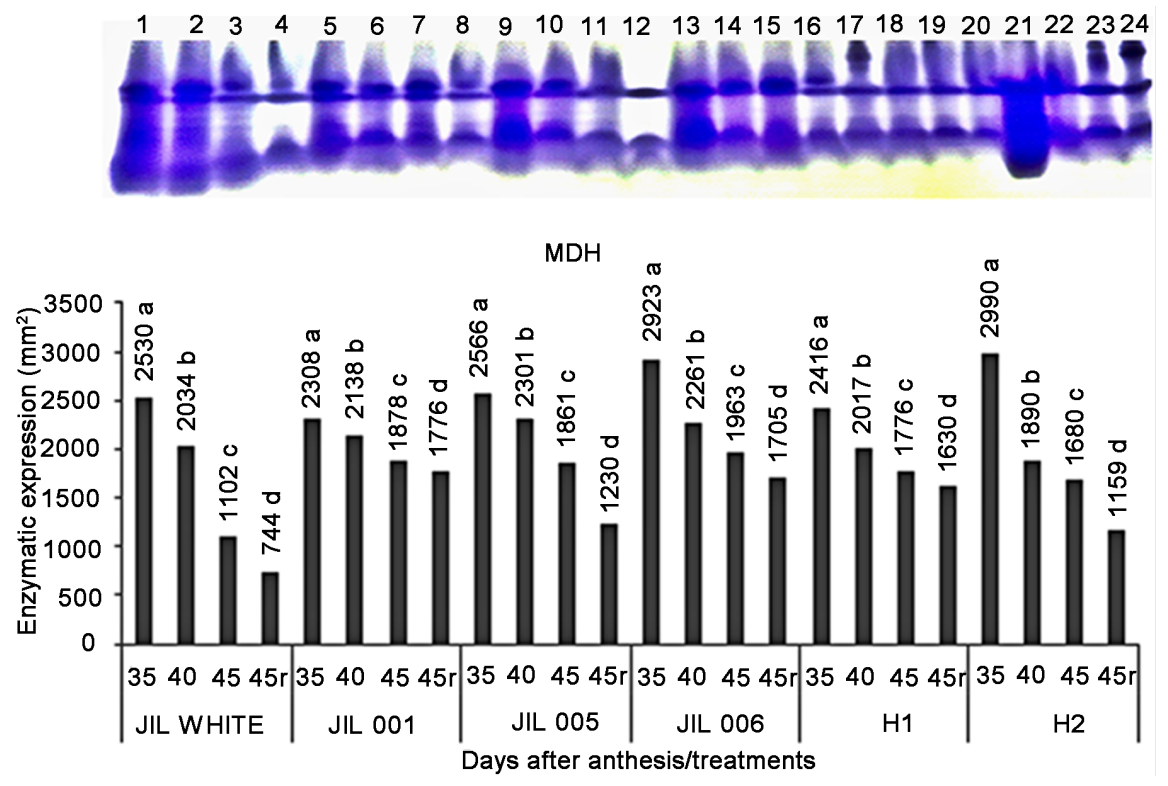

Figure 4. Expressions of the malate dehydrogenase (MDH) enzyme of Jilo seeds of the varieties (JIL white, JIL 001, JIL 005, JIL 006, H1 and H2), harvested at different maturation stages (35, 40, 45 DAA and 45 DAAr). 
At the early stages of development, Jilo seeds had high water content (Figure 1 ), and there was also a progressive increase in the weight of one thousand seeds (Table 1).

Taiz and Zeiger [38] reported that developing storage organs need more energy supply and, therefore, the respiratory activity in these tissues is more intense. According to Peske et al. [39] the high water content of the seeds also causes a significant increase in the respiratory rate.

Thus, there was an increase in the enzymatic expressions of MDH in the early development stages of Jiló seeds, and with a progressive decrease of the enzymatic expression with maturation advancement. These results are related to the fact that, in the beginning of the development of the seeds 35 and 40 DAA, there is a higher water content, increase in dry mass and high respiratory activity. As for mature harvested seeds (40 DAA and $45 \mathrm{DAAr}$ ), there is lower water content, stabilization of dry matter accumulation and the seed shows a state of quiescence with less respiratory and metabolic activity.

Alterations in the enzymatic activities during maturation stages of pepper seeds (Capsicum annuum L.) and (Capsicum frutescens L.) were not found in studies by Vidigal et al. [40], Queiroz et al. [35].

Therefore, this enzyme could be an interesting marker of the aerobic respiration of seeds during the stages of maturation.

Because it is an important enzyme of cellular respiration, the increase in expression in different cellular compartments may be related to increased respiration, which occurs in seeds that are in process of deterioration, since enzymes involved in respiration can be activated in seeds of reduced physiological potential [41]. The lowest values of germination and vigor were found in seeds harvested at early maturation stages.

It is also worth noting that the activity of malate dehydrogenase (MDH) occurs continuously, since the energy generated in the Krebs cycle is fundamental, both for the biosynthesis reactions of products and the degradation of compounds for the growth of the seedling [42].

\subsection{Alcohol Dehydrogenase}

Another enzyme involved in the respiration process is the alcohol dehydrogenase, $\mathrm{ADH}$. In this research, the expressions of enzyme alcohol dehydrogenase varied in different stages of maturation.

The highest expressions for all genetic materials used were found in seeds harvested at early stages of development (35 and $40 \mathrm{DAA}$ ), and the lowest in mature seeds (45 DAA and 45 DAAr).

Increased activity of the enzyme alcohol dehydrogenase (ADH) may be related to increased anaerobic respiration due to the presence of high rates of acetaldehyde, which favors the production of ethanol, which is also toxic to cells (Figure 5).

$\mathrm{ADH}$ is related to anaerobic respiration, promoting the reduction of acetaldehyde to ethanol [43]. Acetylated peptides accelerate seed deterioration [44]. 

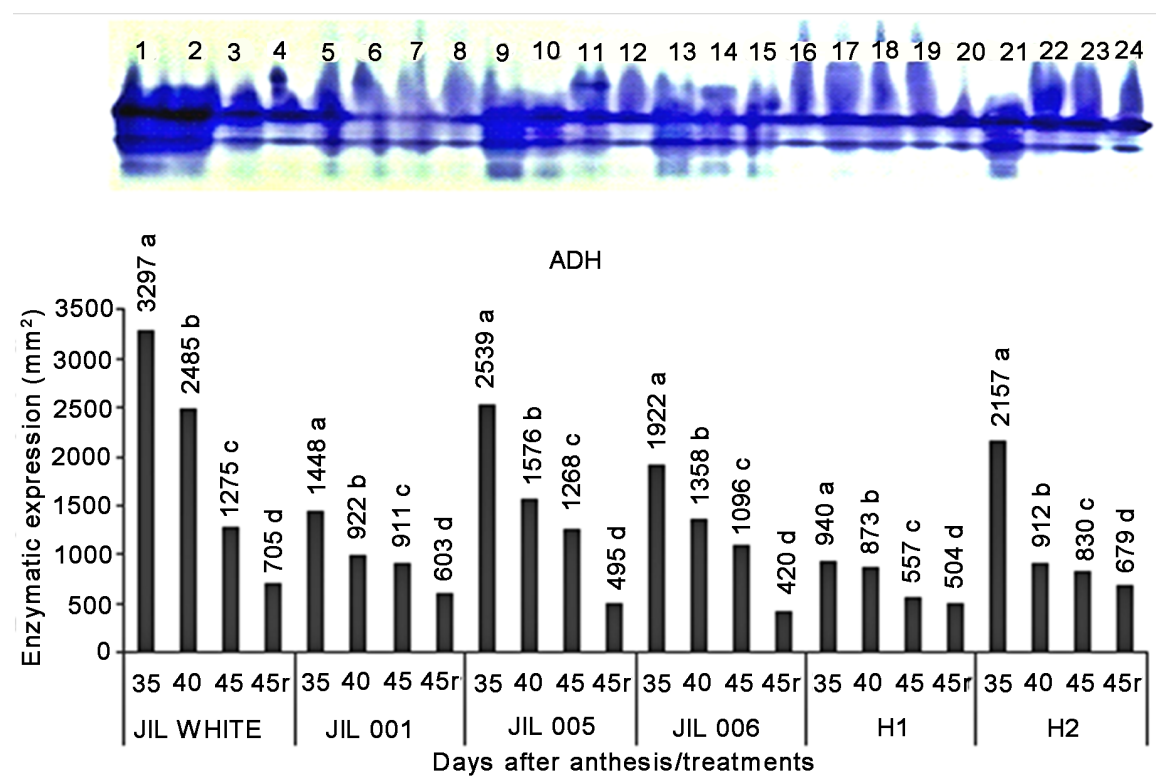

Figure 5. Expressions of the enzyme alcohol dehydrogenase (ADH) of Jilo seeds of the varieties (JIL white, JIL 001, JIL 005, JIL 006, H1 and H2), harvested at different maturation stages $(35,40,45 \mathrm{DAA}$ and $45 \mathrm{DAAr})$.

As ADH activity increases, the seeds are more protected against the deleterious action of this compound, which is higher than that of ethanol.

In seeds harvested at more advanced stages of maturation, the lowest expressions of $\mathrm{ADH}$ are probably related to the reduction of anaerobic respiration [43]. Lower ADH enzyme expression was found in seeds harvested at more advanced maturation stages, at $40 \mathrm{DAA}$ and $45 \mathrm{DAAr}$, respectively.

In addition to the variation of the expression of this enzyme in seeds with different levels of maturation, there was also variation in the expression of different genetic material. Higher expression was found in seeds of white Jiló (JIL white) and lower in seeds of hybrid (H1), considering the seeds in different levels of maturation.

When the aerobic route is compromised, the anaerobic pathway of respiration is activated and products which are toxic to the cells like acetaldehyde and ethanol are accumulated. In anaerobic metabolism, pyruvate, primarily produced in glycolysis, is converted to acetaldehyde by the action of the enzyme pyruvate decarboxylase and acetaldehyde is then reduced to ethanol by the enzyme alcohol dehydrogenase (ADH).

In a study Zhang et al. [44], volatile production by seeds occurred due to anaerobic metabolism, whose presence may accelerate their deterioration process. According to Zhang et al. [44], among volatile compounds, acetaldehyde provided the most harmful effects regardless of the storage environment, which accelerated the deterioration process.

In a study carried out by Vidigal et al. [40], greater expression was found in pepper seeds obtained from fruits harvested at later maturation stages (60 and 70 DAA-red fruits). 
According to Santos et al. [45], there is increased respiration in seeds that are in a deteriorating process, since the enzymes involved in respiration, such as $\mathrm{ADH}$ and $\mathrm{MDH}$, can be activated in seeds with reduced physiological quality.

\subsection{Superoxide Dismutase; Catalase and Peroxidase}

In relation to the enzymes superoxide dismutase (SOD), catalase (CAT) and peroxidase (PO), these presented similar behavior regarding their expression. There was higher expression of these enzymes in seeds harvested at the initial stages of maturation, mainly at 35 and 40 DAA. Reductions of these expressions occurred with the advancement of seed maturation, at 45 DAA and 45 DAAr.

There were variations of the expressions of these three enzymes also in seeds of the different genetic materials used. For peroxidase, catalase and superoxide dismutase, for example, lower expression was found in $\mathrm{H} 2$ hybrid seeds (Figures 6-8).

The highest expression of the enzyme (SOD) occurred at the early stages of the seed maturation process (35 and $40 \mathrm{DAA}$ ), indicating that its defense action, to reduce superoxide $\left(\mathrm{O}_{2}^{-}\right)$, and consequent reduction of free radical formation, was more demanded, either due to the deterioration process or the immaturity of the seeds at the initial stages.

As a result of the action of SOD, which converts $\mathrm{O}_{2}^{-}$into $\mathrm{H}_{2} \mathrm{O}_{2}$ and $\mathrm{O}_{2}$, enzymes (CAT) and (PO) will convert $\mathrm{H}_{2} \mathrm{O}_{2}$ which may also be harmful to plant cells in $\mathrm{O}_{2}$ and $\mathrm{H}_{2} \mathrm{O}$. In this process there is involvement of these enzymes, which can be found in SOD, CAT, and PO patterns.

Reactive oxygen species (ROS) have a dual role in seed physiology, presenting beneficial or detrimental effects providing important information for the
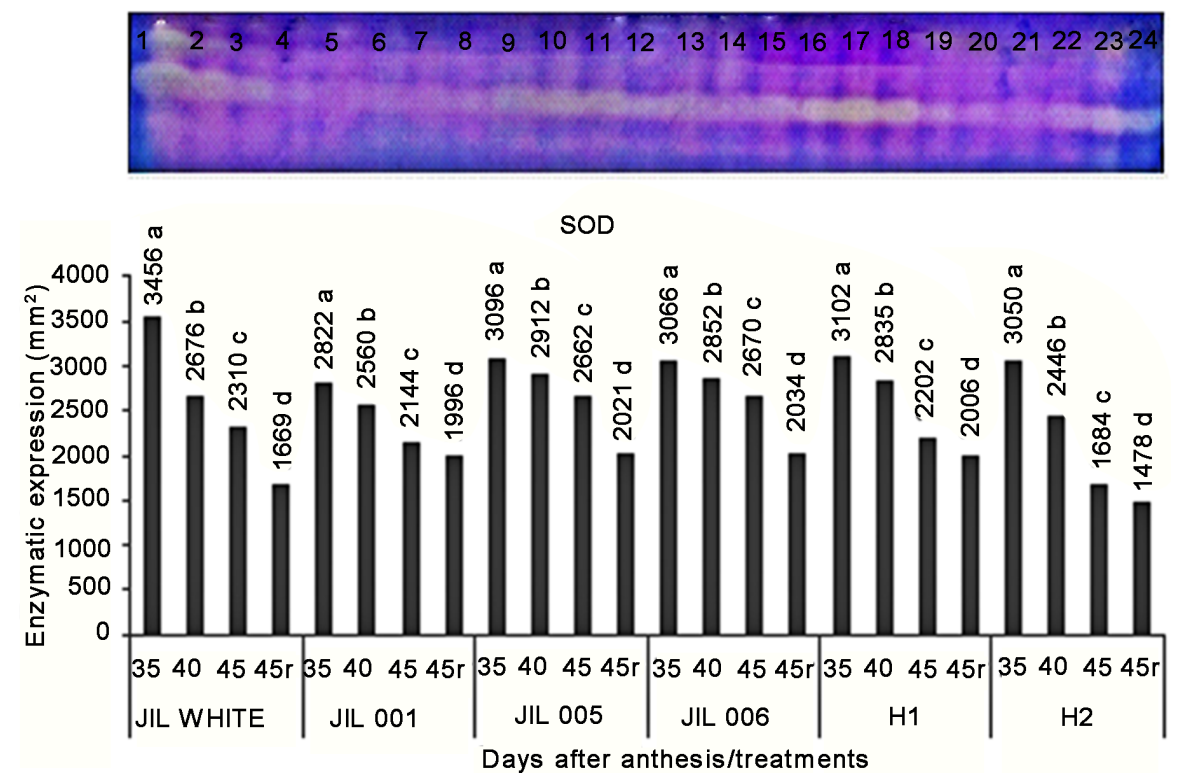

Figure 6. Superoxide dismutase (SOD) expression of Jiló seeds (JIL white, JIL 001, JIL 005, JIL 006, H1 and H2), harvested at different stages of maturation $(35,40,45 \mathrm{DAA}$ and 45 DAAr). 

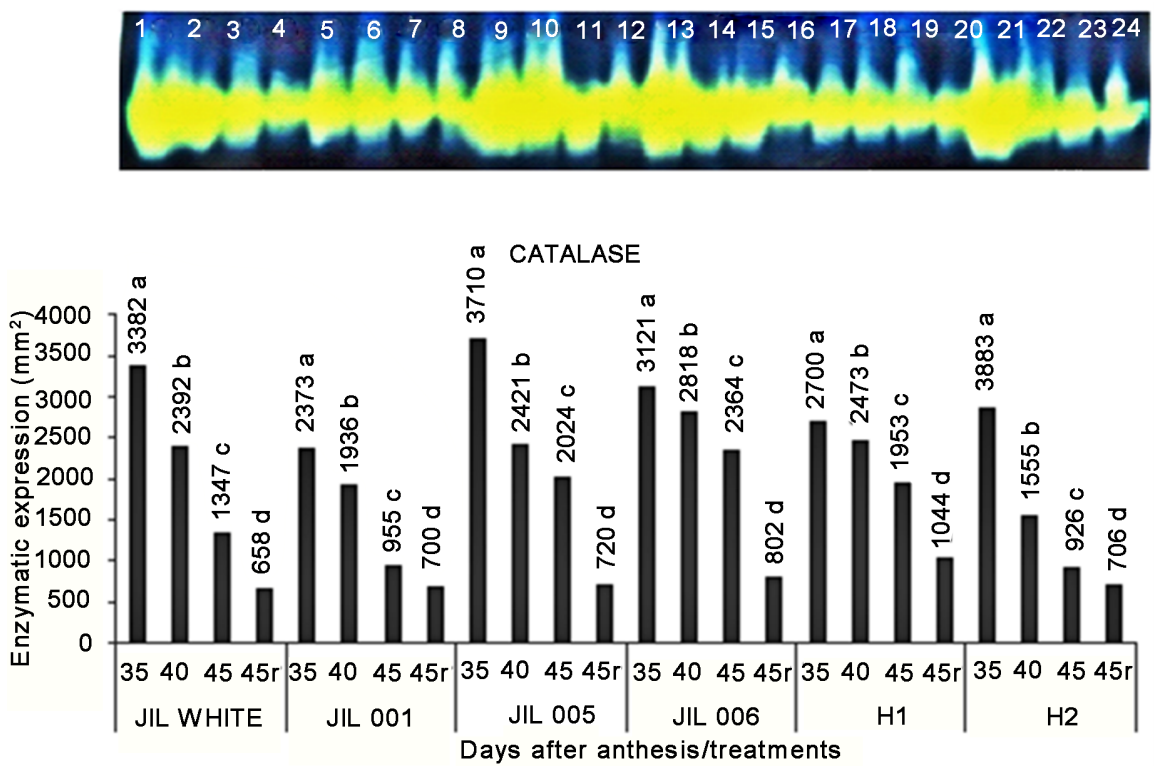

Figure 7. Catalase expression (CAT) of Jiló seeds (JIL white, JIL 001, JIL 005, JIL 006, H1 and $\mathrm{H} 2$ ), harvested at different maturation stages (35, 40, 45 DAA and 45 DAAr).
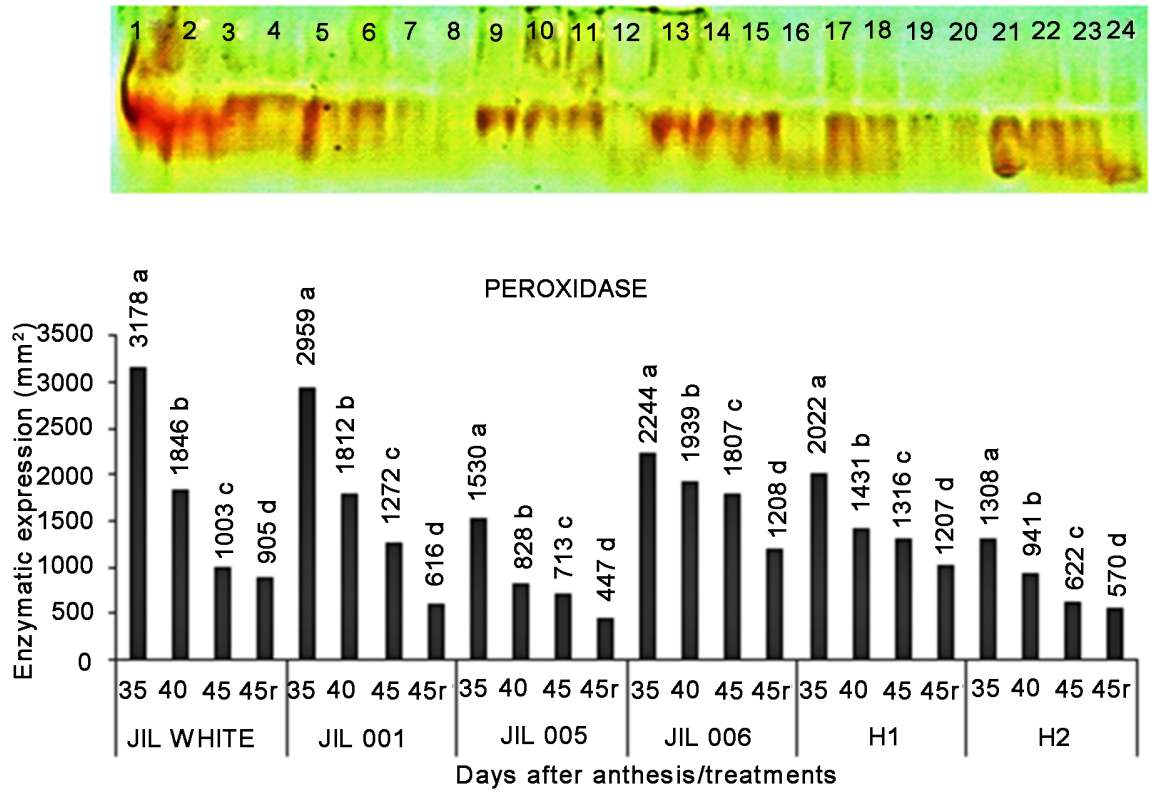

Figure 8. Peroxidase expression (PO) of Jiló seeds (JIL white, JIL 001, JIL 005, JIL 006, H1 and $\mathrm{H} 2)$, harvested at different maturation stages $(35,40,45$ DAA and 45 DAAr).

maintenance of seed vigor and quality of cultivated plants, as well as an important role during germination [46].

Superoxide dismutase (SOD) is the first enzyme in the plant defense line to eliminate ROS, converting $\mathrm{O}_{2}^{-}$into $\mathrm{H}_{2} \mathrm{O}_{2}$ and $\mathrm{O}_{2}$. However, $\mathrm{H}_{2} \mathrm{O}_{2}$ can also be harmful to plant cells, so catalase (CAT) and peroxidase (PO) can convert $\mathrm{H}_{2} \mathrm{O}_{2}$ to $\mathrm{O}_{2}$ and $\mathrm{H}_{2} \mathrm{O}$.

Marcos Filho [18] reported that the increase in the activity of these enzymes is associated with the deterioration of seeds due to the need for more intense activ- 
ity of enzymes participating in the antioxidant complex.

Seeds from fruits harvested at the initial stages of development 35 and 40 DAA were probably more exposed to oxidative stress, favoring lipid peroxidation, which corroborates with the claims of Yamauchi et al:; Monteiro et al. [47] [48]. Superoxide dismutase, catalase (CAT) and peroxidase (PO) were probably associated with the defense function of the reactive oxygen species (ROS), converting $\mathrm{O}_{2}^{-}$into $\mathrm{H}_{2} \mathrm{O}_{2}$ and $\mathrm{O}_{2}$, and the highest expression of the superoxide dismutase isoenzyme (SOD), catalase $\mathrm{H}_{2} \mathrm{O}_{2}$ in $\mathrm{O}_{2}$ and $\mathrm{H}_{2} \mathrm{O}$, successively, mainly in immature seeds.

In seeds from fruits harvested at more advanced stages of maturation, the expressions of these enzymes were smaller than 45 DAA and 45 DAAr.

Seed quality, lower values of electrical conductivity, greater weight of one thousand seeds, fresh and dry matter of seedlings, and higher and maximum values of germination, IVG, emergence and IVE were found for seeds submitted to the 45 DAAr treatment in the results found in the seed quality evaluation tests.

Abiotic stress conditions may favor the increase in the formation of reactive oxygen species [49] [50]. Increase of ROS can react with unsaturated fatty acids of cell membranes, promoting lipid peroxidation [47] [48].

Enzymes involved in degradation, such as esterase (EST), malate dehydrogenase $(\mathrm{MDH})$, alcohol dehydrogenase $(\mathrm{ADH})$, catalase $(\mathrm{CAT})$ and peroxidase (PO) have great potential as molecular markers to monitor and characterize the physiological quality of seeds [51], besides providing an understanding of causes of vigor and reduced viability [52].

\subsection{Endo- $\beta$-Mannanase}

In relation to the activity of enzyme endo- $\beta$-mannanase, it is possible to verify a greater expression of this enzyme in seeds from fruits harvested at $45 \mathrm{DAAr}$ (fruits harvested at $45 \mathrm{DAA}$ and that remained 7 days at rest).

The expression of endo- $\beta$-mannanase enzyme in seeds from fruits harvested at $45 \mathrm{DAAr}$ for all evaluated genetic materials was statistically superior to seeds harvested at less advanced stages of maturation. Due to the interaction between genetic materials and maturation stages, the highest expression of endo- $\beta$-mannanase was found in seeds of cultivars subject to 45 DAAr treatment (Figure 9).

The increase in enzyme expression of endo- $\beta$-mannanase according to the maturation stages (from $35 \mathrm{DAA}$ to $45 \mathrm{DAAr}$ ) in seeds of all genetic material may be associated with results obtained in the tests for evaluation of physiological quality. There was a progressive increase in the values of root protrusion, germination and emergence of seedlings with advancement of the seed maturation process.

The rupture of the endosperm is the main limitation during the germination of solanaceous seeds and, in this case, it is necessary to weaken the micropillary endosperm that surrounds the end of the radicle, that is, hydrolysis of the 


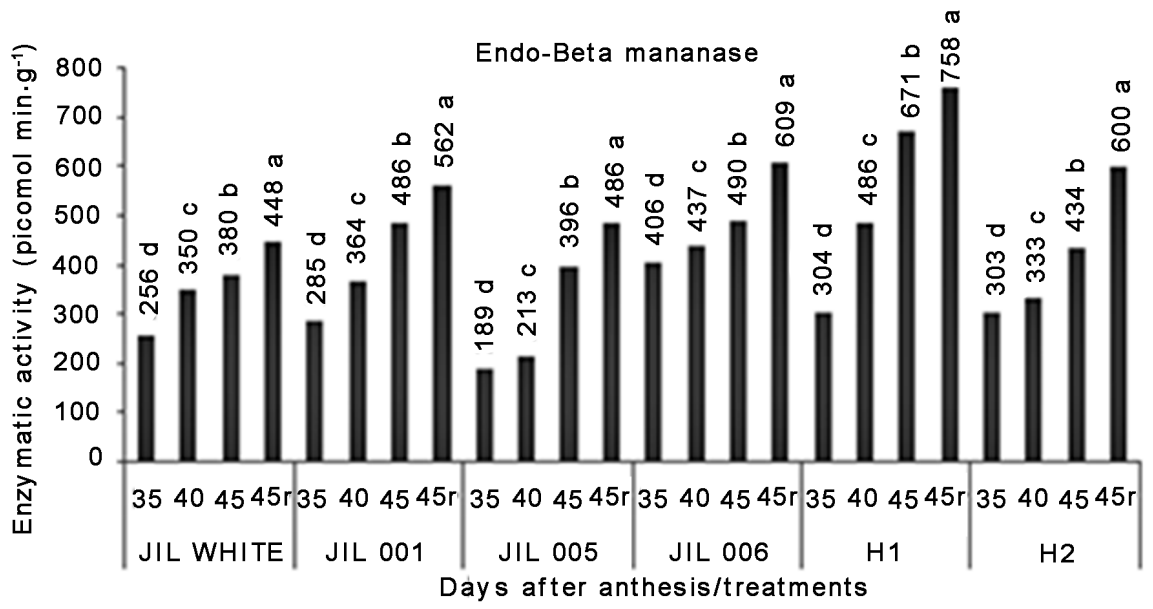

Figure 9. Expression of endo- $\beta$-mannanase from Jiló seeds (JIL white, JIL 001, JIL 005, JIL 006, H1 and H2), harvested at different maturation stages (35, 40, 45 DAA and 45 DAAr) (means followed by the same lower case letter in the bars of each treatment do not differ from each other by the Scott-Knott Test at $5 \%$ probability).

endosperm cell wall occurs by hydrolytic enzymes, such as endo-B-mannanase [23] [53] [54].

Caixeta; Queiroz et al. [23] [35], working with habanero and chilli pepper seeds harvested at different stages of development, found an increase in endo- $\beta$-mannanase enzyme expression in seeds harvested at more advanced stages of development.

Also, in tomato seeds, the softening of the endosperm is directly linked to the increase of endo- $\beta$-mannanase enzyme expression [55].

Through the results obtained in this work it was possible to verify the ideal harvest point for Jiló seeds. However, there was a discrepancy among the genetic materials, especially the hybrids that presented the best values for germination and vigor. Therefore, further studies involving both genetic control and genes expression related to the physiological quality of Jiló seeds should be carried out.

\section{Conclusions}

Seeds from fruits harvested at 45 days after anthesis and submitted to rest for seven days (45 DAAr) show higher values of germination, vigor and dry weight. The highest values of lipids and proteins and lower values carbohydrates in Jiló seeds were observed in the initial maturation stages. Expressions of the enzymes Esterase, Isocitrato Liase, Malate Dehydrogenase, Alcohol Dehydrogenase, Superoxide Dismutase, Catalase and Peroxidase present higher expression in the initial stages of maturation, mainly at 35 and $40 \mathrm{DAA}$, however the expression of endo- $\beta$-mananse increases with advancing stages of maturity, with the highest expression at 45 DAAr. There was significant interaction between genotype and harvest time, where the hybrids $\mathrm{H} 1$ and $\mathrm{H} 2$ had the highest values from $45 \mathrm{DAA}$ and maximum values for all the genetics materials at 45 DAAr, being the ideal harvest point at $45 \mathrm{DAA}$ with seven days at rest (45 DAAr). 
Through this study it was possible to determine the ideal harvest point and to differentiate genetic material with high and low physiological quality. With this it is possible to harvest fruits at the appropriate time with high physiological quality seeds, besides to save agricultural inputs, labor and possible losses due to environmental conditions.

\section{Acknowledgements}

To Capes (Coordination for the Improvement of Higher Level Personnel); National Council for Scientific and Technological Development (CNPq) and the Foundation for Research Support of the State of Minas Gerais (FAPEMIG).

\section{Conflict of Interests}

The authors declare no conflict of interest.

\section{Author Contribution}

All the authors have contributed in the present work with respect to the concept, experiments conducted, data analysis and preparation of the manuscript. All the authors have unanimously agreed upon to be equally accountable in ensuring the accuracy and integrity of any part of the work.

\section{References}

[1] Abud, H.F., Araujo, E.F., Araujo, R.F., Araujo, A.V. and Pinto, C.M.F. (2013) Physiological Quality of Seeds of Chili Peppers and Pussy during Ontogenesis. Brazilian Agricultural Research, 48, 1546-1554.

[2] Alvarenga, E., Silva, R., Araújo, E. and Cardoso, A. (1984) Influence of Age and Post-Harvest Storage of Fruits as Watermelon Seeds. Brazilian Horticulture, 2, 5-8.

[3] Birth, W.M.F. (2006) Production of Seeds of Peppers. In: Ribeiro, C.S.C., Henz, G.P., Carvalho, S.I.C. and Lopes, C.A., Eds., Cultivation of Peppers (Capsicum spp.) in Brazil, Embrapa Hortaliças, Brasília, 30-39.

Http://www.scielo.br/scielo.php?script=sci_nlinks\&ref=000145\&pid=S01013122201 $100030001000027 \& \operatorname{lng}=$ en

[4] Filgueira, FARF (2003) Solanaceae: Modern Agro-Technology in the Production of Tomatoes, Potatoes, Peppers, Aubergines and Jiló. Ufla, 333.

http://www.scielo.br/scielo.php?script=sci_nlinks\&ref=000096\&pid=S18066690201 $100040002600007 \& \operatorname{lng}=\mathrm{en}$

[5] Mangan, F., Moreira, M. and Martuscelli, T. (2009) Seed Production and Marketing to the Population of Portuguese Speakers in Massachusets. University of Massachusets.

http://www.umassvegetable.org/growers_services/pdf_files/portuguese_crops_engli sh.pdf

[6] Berger, F., Hamamura, Y., Ingouff, M. and Higashiyama, T. (2008) Double Fertilization-Caught in the Act. Trends in Plant Science, 13, 437-443.

[7] Hehenberger, E., Kradolfer, D. and Köhler, C. (2012) Endosperm Cellularization Defines an Important Developmental Transition for Embryo Development. Development, 139, 2031-2039. https://doi.org/10.1242/dev.077057

[8] Silva, R.P., Teixeira, I.R., Devilla, I.A., Rezende, R.C. and da Silva, G.C. (2011) Phy- 
siological Quality of Soybean Seeds (Glycine max L.) Seeds during Processing. Semina: Agrarian Sciences, 32, 1219-1230.

Http://www.scielo.br/scielo.php?script=sci_nlinks\&ref=000087\&pid=S23171537201 300010000700017\&lng=en

[9] Alves, C.Z., Godoy, A.R., Candido, A.C.d.S. and Oliveira, N.C. (2012) Physiological Quality of Jiló Seeds by the Accelerated Aging Test. Rural Science, 42, 58-63. https://doi.org/10.1590/S0103-84782012000100010

[10] Brazil (2009) Ministry of Agriculture, Livestock and Supply. Rules for Seed Analysis. Secretariat of Agricultural and Livestock Defense. MAPA/ACS, Brasília, 395. http://www.agricultura.gov.br/arq_editor/file/laborat\%c3\%b3rio/sementes/regras\% 20para\%20analise $\% 20 \mathrm{de} \% 20$ sementes.pdf

[11] Torres, S.B. and Pereira, R.A. (2010) Electric Conductivity in Arugula Seeds. Brazilian Journal of Seeds, 32, 58-70.

[12] Maguire, J.D. (1962) Speed of Germination-Aid in Selection and Evaluation for Seedling Emergence and Vigor. Crop Science, 2, 176-177.

Http://www.scielo.br/scielo.php?script=sci_nlinks\&ref=000056\&pid=S01002945200 500020004100008\&lng=en https://doi.org/10.2135/cropsci1962.0011183X000200020033x

[13] AOAC (2000) AOAC (Association of Official Analytical Chemists) Official Methods of Analysis. University of Michigan: Association of Official Anaiytical Chemists.

Http://periodicos.ses.sp.bvs.br/scielo.php?script=sci_nlinks\&ref=161452\&pid=S007 $\underline{39855200600030001000001 \& \operatorname{lng}=\mathrm{en}}$

[14] Alfenas, A.C. (2006) Electrophoresis and Biochemical Markers in Plants and Microorganisms, UFV, 2, 627.

Https://www.editoraufv.com.br/produto/1590467/eletroforese-and-marquimicos-in - plantas-e-microorganismos-2

[15] Ferreira, D.F. (2008) SISVAR: A Program for Analysis and Teaching of Statistics. In: Review Symposium, Vol. 6, 36-41, Lavras.

Http://www.scielo.br/scielo.php?script=sci_nlinks\&ref=000094\&pid=S14137054201 $100060002000012 \& \operatorname{lng}=$ en

[16] Scott, A.J. and Knott, M. (1974) A Cluster Analysis Method for Grouping Means in the Analysis of Variance. Biometrics, 30, 507-512. https://doi.org/10.2307/2529204

[17] Carvalho, N. and Nakagawa, J. (2000) Seeds: Science, Technology and Production. 4th Edition, FUNEP, Jaboticabal.

Http://www.scielo.br/scielo.php?script=sci_nlinks\&ref=000071\&pid=S01038478201 200120001500007\&lng=en

[18] Marcos Filho, J. (2015) Seed Physiology of Cultivated Plants, Fealq. Embrapa Soja, 659.

https://www.bdpa.cnptia.embrapa.br/consulta/busca?b=ad\&biblioteca=vazio\&busca =autoria:\%22MARCOS\%20FILHO,\%20J.\%22

[19] Bewley, J.D., Bradford, K.J., Hilhorst, H.W.M. and Nonogaki, H. (2013) Seeds: Physiology of Development, Germination and Dormancy. Springer, New York, Heidelberg, Dordrecht, London, 392 p. https://doi.org/10.1017/S0960258513000287

[20] Nakada, P.G., Oliveira, J.A., Melo, L.C.D., Gomes, L.A.A. and Von Pinho, É.V.D.R. (2011) Physiological and Biochemical Performance of Cucumber Seeds at Different Maturation Stages. Brazilian Journal of Seeds, 33, 113-122.

[21] Miranda, Z., Mello, V., Santos, D., Tillmann, M., Santos, A. and Silva, J. (1992) Quality Evaluation of Eggplant Seeds (Solanum melongena L.). Brazilian Journal of 
Seeds, 14, 125-129.

http://www.scielo.br/scielo.php?Script=sci_nlinks\&ref=000062\&pid=S01013122200 $800020002900006 \& \operatorname{lng}=\mathrm{en}$

[22] Oliveira, A., Gonçalves, C., Bruno, R. and Alves, E. (1999) Physiological Maturation of Chili Seeds, as a Function of Fruit Age after Anthesis. Brazilian Journal of Seeds, 21, 88-94.

Http://www.scielo.br/scielo.php?script=sci_nlinks\&ref=000105\&pid=S01013122200 900020001500020\&lng=en

[23] Caixeta, F., Von Pinho, É.V.d.R., Guimarães, R.M., Pereira, P.H.A.R., Catão, H.C.R.M. and Clemente, A.d.C.S. (2014) Determination of the Harvest Point in the Production of Chilli Pepper Seeds and Biochemical Changes during Storage and Germination. Science, 42, 187-197.

[24] Pereira, F.E.C.B., Torres, S.B., Lima Silva, M.I., Grangeiro, L.C. and Benedito, C.P. (2014) Physiological Quality of Pepper Seeds as a Function of Age and Post-Harvest Time of Fruits. Agronomic Science, 45, 737-744.

[25] Martins, D.C., Vilela, F.K., Guimarães, R.M., Gomes, L.A.A. and Silva, P.A.d. (2012) Physiological Maturity of Eggplant Seeds. Brazilian Journal of Seeds, 34, 534-540. https://doi.org/10.1590/S0101-31222012000400002

[26] Silva, R., Araújo, E. and Viggiano, J. (2009) Extraction of Seeds of Fleshy Fruits of Vegetables. Birth, WM Vegetable Seed Technology. Embrapa Hortaliças, Brasília, 77-102.

Http://www.scielo.br/scielo.php?script=sci_nlinks\&ref=000087\&pid=S23171537201 300010000700017\&lng=en

[27] Castro, M.M. and Cardoso, A.I. (2004) Quality of Jiló Seeds, "Morro Grande" as a Function of Age and Fruit Storage. Vol. 22, 418.

http://www.scielo.br/scielo.php?script=sci_nlinks\&ref=000062\&pid=\$18066690201 400040001100004\&lng=en

[28] Silva, P.P., Freitas, R.A., Cicero, S.M., Marcos-Filho, J. and Nascimento, W.M. (2014) Image Analysis in the Morphological and Physiological Study of Pumpkin Seeds. Horticultura Brasileira, 32, 210-214. https://doi.org/10.1590/S0102-05362014000200016

[29] Santos, H., Von Pinho, E., Von Pinho, I., Dutra, S. andrade, T. and Guimarães, R. (2015) Physiological Quality and Gene Expression during the Development of Habanero Pepper Capsicum Chinense Jacquin Seeds. Genetics and Molecular Research, 14, 5085-5098. https://doi.org/10.4238/2015.May.12.11

[30] Justino, E.V., Boiteux, L.S., Fonseca, M.E., Silva Filho, J.G. and Nascimento, W.M. (2015) Determination of Physiological Maturity of Peppercorn Seeds Capsicum baccatum var. Pendulum. Horticultura Brasileira, 33, 324-331. https://doi.org/10.1590/S0102-053620150000300008

[31] Gutierrez, L., Van Wuytswinkel, O., Castelain, M. and Bellini, C. (2007) Combined Networks Regulating Seed Maturation. Trends in Plant Science, 12, 294-300.

[32] Graham, I.A. (2008) Seed Storage Oil Mobilization. Annual Review of Plant Biology, 59, 115-142. https://doi.org/10.1146/annurev.arplant.59.032607.092938

[33] Leprince, O. and Buitink, J. (2010) Desiccation Tolerance: From Genomics to the Field. Plant Science, 179, 554-564.

[34] Lima, R.B.S., Gonçalves, J.F.C., Pando, S.C., Fernandes, A.V. and Santos, A.L.W.d. (2008) Primary Metabolite Mobilization during Germination in Rosewood (Aniba rosaeodora Ducke) Seeds. Revista Árvore, 32, 19-25.

Http://www.scielo.br/scielo.php?script=sciarttext\&pid=s010067622008000100003 
https://doi.org/10.1590/S0100-67622008000100003

[35] Queiroz, L.A.F., Pinho, É.V.d.R.V., Oliveira, J.A., Ferreira, V.d.F., Carvalho, B.O. and Bueno, A.C.R. (2011) Harvest and Drying Season as Habanero Yellow Pepper Seeds. Brazilian Journal of Seeds, 33, 472-481.

[36] Santos, C.M., MENEZES, N.d. and Villela, F.A. (2004) Physiological and Biochemical Changes in Artificially Aged Bean Seeds. Brazilian Journal of Seeds, 26, 110-119.

[37] Bewley, J. (1994) Some Ecophysiological Aspects of Germination. In: Bewley, J.D. and Black, M., Eds., Seeds. Physiology of Development and Germination, Plenum Press, New York. Http://www.springer.com/us/book/9783642686450 https://doi.org/10.1007/978-1-4899-1002-8_6

[38] Taiz, L. and Zeiger, E. (2004) Plant Physiology. 3th Edition, Artmed, Porto Alegre, 719-565.

http://www.scielo.br/scielo.php?script=sci_nlinks\&ref=000091\&pid=S01013122200 700020000300016\&lng=en

[39] Peske, S., Lucca Filho, A. and Barros, A. (2006) Seed Production in: Seeds: Scientific and Technological Foundations. 2nd Edition.

Http://www.scielo.br/scielo.php?script=sci_nlinks\&ref=000096\&pid=S23171532013 00040000800025\&lng=en

[40] Vidigal, D.D., Dias, D., Pinho, E. and Dias, L.d.S. (2009) Physiological and Enzymatic Changes during the Maturation of Pepper Seeds (Capsicum annuum L.). Brazilian Journal of Seeds, 31, 129-136.

[41] Shatters, R.G., Abdelghany, A., Elbagoury, O. and West, S. (1994) Soybean Seed Deterioration and Response to Osmotic Priming: Changes in Specific Enzyme Activities in Extracts from Dry and Germinating Seeds. Seed Science Research, 4, 33-41. https://doi.org/10.1017/S0960258500001975

[42] Moreland, D.E. and Novitzky, W.P. (1988) Interference by Flavone and Flavonols with Chloroplast-Mediated Electron Transport and Phosphorylation. Phytochemistry, 27, 3359-3366.

[43] Buchanan, B.B., Gruissem, W. and Jones, R.L. (2015) Biochemistry and Molecular Biology of Plants. John Wiley \& Sons. Http://www.wiley.com/WileyCDA/WileyTitle/productCd-0470714212.html

[44] Zhang, Y., Dorjpalam, B. and Ho, C.T. (1992) Contribution of Peptides to Volatile Formation in the Maillard Reaction of Casein Hydrolysate with Glucose. Journal of Agricultural and Food Chemistry, 40, 2467-2471. https://doi.org/10.1021/jf00024a026

[45] Santos, C.M., Menezes, N.d. and Villela, F.A. (2005) Physiological and Biochemical Changes in Bean Seeds in Storage. Brazilian Journal of Seeds, 27, 104-114.

[46] Kumar, S., Rajendra Prasad, S., Banerjee, R. and Thammineni, C. (2015) Seed Birth to Death: Dual Functions of Reactive Oxygen Species in Seed Physiology. Annals of Botany, 116, 663-668. https://doi.org/10.1093/aob/mcv098

[47] Yamauchi, Y., Furutera, A., Seki, K., Toyoda, Y., Tanaka, K. and Sugimoto, Y. (2008) Malondialdehyde Generated from Peroxidized Linolenic Acid Causes Modification in Heat-Stressed Plants. Plant Physiology and Biochemistry, 46, 786-793.

[48] Monteiro, C.C., Carvalho, R.F., Gratão, P.L., Carvalho, G., Tezotto, T., Medici, L.O., Peres, L.E. and Azevedo, R.A. (2011) Biochemical Responses of the Ethylene-Insensitive Never Ripe Tomato Mutant Subjected to Cadmium and Sodium Stresses. Environmental and Experimental Botany, 71, 306-320.

Http://www.scielo.br/pdf/aabc/v84n2/aop2212.pdf 
[49] Gill, S.S. and Tuteja, N. (2010) Reactive Oxygen Species and Antioxidant Machinery in Abiotic Stress Tolerance in Crop Plants. Plant Physiology and Biochemistry, 48, 909-930.

[50] Gomes, M.P. and Garcia, Q.S. (2013) Reactive Oxygen Species and Seed Germination. Biology, 68, 351-357. https://doi.org/10.2478/s11756-013-0161-y

[51] Veiga, A.D., Pinho, É.V.d.R.V., Veiga, A.D., Pereira, P.H.A.R., Oliveira, K.C. and Pinho, R.G.V. (2010) Influence of Potassium and Liming on Chemical Composition, Physiological Quality and Enzymatic Activity of Soybean Seeds.

[52] Araújo, F., Karsten, J. and Finger, F.L. (2014) Physiological and Enzymatic Changes in Corn Seeds Submitted to Different Harvesting Times and Threshing Methods. Brazilian Journal of Corn and Sorghum, 13, 14-23.

[53] Mo, B. and Bewley, J.D. (2003) The Relationship between $\beta$-Mannosidase and Endo- $\beta$-Mannanase Activities in Tomato Seeds during and Following Germination: A Comparison of Seed Populations and Individual Seeds. Journal of Experimental Botany, 54, 2503-2510. https://doi.org/10.1093/jxb/erg274

[54] Kucera, B., Cohn, M.A. and Leubner-Metzger, G. (2005) Plant Hormone Interactions during Seed Dormancy Release and Germination. Seed Science Research, 15, 281-307. https://doi.org/10.1079/SSR2005218

[55] Nonogaki, H., Matsushima, H. and Morohashi, Y. (1992) Galactomannan Hydrolyzing Activity during Priming in the Micropylar Endosperm Tip of Tomato Seeds. Physiology Plantarum, 85, 167-172.

https://doi.org/10.1111/j.1399-3054.1992.tb04719.x

Submit or recommend next manuscript to SCIRP and we will provide best service for you:

Accepting pre-submission inquiries through Email, Facebook, LinkedIn, Twitter, etc. A wide selection of journals (inclusive of 9 subjects, more than 200 journals)

Providing 24-hour high-quality service

User-friendly online submission system

Fair and swift peer-review system

Efficient typesetting and proofreading procedure

Display of the result of downloads and visits, as well as the number of cited articles

Maximum dissemination of your research work

Submit your manuscript at: http://papersubmission.scirp.org/

Or contact ajps@scirp.org 